\title{
質量輸送現象としてとらえた波動場における シートフロー状漂砂現象の解析
}

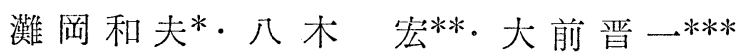

\section{1.はじめに}

現在岸沖漂砂量式と呼ばれるものの多くは, 河川工学 に抢ける流砂量算定法の単純な拡張として, その移動量 を基本的にシールズ数の夕の関数として和り, それに関 連して, 漂砂の net の移動量と移動方向を流速波形の非 対称性だけに基づいて表現する形になっている。これに 対して, 灘岡ら(1988)は, 波動場に怙いては, たとえ流 速波形が正弦的であっても net の漂砂量が生じ得ること を理論解析の結果から指摘している，このことは，波動 場に和ける底質輸送現象に関して, 振動流場のそれと明 確に対比し, その独自の機構をより詳細に検討する必要 性があることを示している.

そこで本研究では, まず波動場に括汸るシートフロー 状底質移動の実態をとらえる目的から, 着色砂を用いた 室内実験によって底質の移動状況を定量的に把握するこ とを試みた。 その結果, 波動場では, 底面近傍の軌道流 速波形が正弦形に十分近い場合に和いても実際にかなり の大きさの net の底質移動が生じることが明らかになっ た.ここではこれを, 水粒子に関するものと同椂な意味 での『底質粒子の質量輸送現象』としてとら光, それを 構成する要素である Euler 平均速度を固定床との比較も 含めて FLDV によって詳細に計測するとともに，この 質量輸送速度に関する理論解析を行うことによってその 特性を明らかにすることを試みた。

\section{2. 質量輸送速度に関する室内実験}

\section{（1）実験装置ならびに実験条件}

実験には, 図一1 に示すよらな長さ $20 \mathrm{~m}$, 幅 $40 \mathrm{~cm}$, 高さ $60 \mathrm{~cm}$ の両面ガラス張りの 2 次元造波水路を用い た.この水槽中には $1 / 20$ 勾配の斜面を設置してあり， ここではその中央部に測定区間として水平床部分約 $2 \mathrm{~m}$ (移動床ないし固定床)を設けて実験を行った。な和実験 条件は, 測定区間に沶いて, 波高 $12 \mathrm{~cm}$, 水深 $25.2 \mathrm{~cm}$, 周期 $1 \mathrm{~s}$ の 1 ケースである.

\footnotetext{
* 正 員 工博 東京工業大学助教授 工学部土木工学科

** 正 員 工修 東京工業大学助手 工学部土木工学科

*** 学生員東京工業大学大学院
}

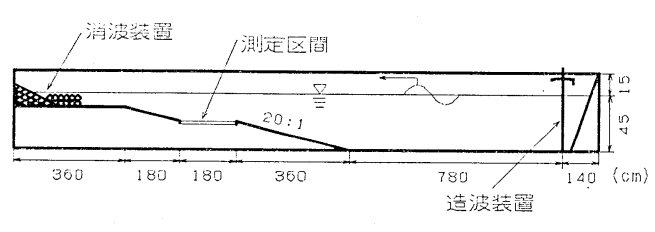

図-1 実験装置

また本研究では, 波動場に拈いてシートフロー状砂移 動が生じている条件下での底質輸送機構を調べることを 目的としていることから, 室内の波動水槽に执いてもシ ートフローが発生するように, 粒子として比重 1.3 , 粒 径 $0.43 \mathrm{~mm}$ の人工軽量粒子 (塩化ビニルコンパウンド) を使用した。

\section{（2） シートフロー層内の質量輸送速度の計測法}

まずはじめに，シートフロー層内に和汀る底質粒子の 質量輸送速度 (Lagrange 的一周期平均移動速度) の計測 方法として，粘性土に対して楖山・Bijker (1988) が用い た方法を参考とし，着色砂を用いた方法を試及た，具体 的には以下のような手順で実験を行った，まずはじめに 測定区間の底質を水平に敷きならして扣き，その一部分 を 2 枚の薄いアクリル板 (間隔 $6 \mathrm{~cm}$ ) で水路側壁に対し て垂直方向に仕切る．次に，この間に挟をれた底質を厚 さ $1.5 \mathrm{~cm}$ にわたりサイホンによって抜さ出し，その代 わりとして黒く着色した粒子を注入する，そうしたの ち，アクリル板を取り除き，表面を整形して初期の状態 と同様に水平にし，波を 50 波作用させた.

後で詳しく述べるょうに, 波作用後の着色砂の空間分 布データからシートフロー層内での着色砂の平均移動速 度を求めることができるが，これは層内で鉛直方向に平 均した質量輸送速度に他ならない，そこで本研究ではさ らに移動層内に物ける質量輸送速度の鉛直分布まで計湘 するために，以下のような手法で質量輸送速度を計測す ることを試みた。

まず，底質粒子中に適発な濃さで着色粒子を混ぜ合わ せておき，その運動をビデオカメラで撮影する．次に， シートフロー層内の着色粒子に着目して, その粒子の速 度の反転時から次の反転時むで（約半周期間）に岸向き 
もしくは沖向きに移動した距離をビデオ画像から読みと る.さらに，こうして得られた粒子岸沖移動距離の生デ 一タを，鉛直方向に間隔 $0.5 \mathrm{~mm}$ ごとに平均して，その 中心の位置での岸・沖平均移動距離とし, その差から net の移動距離を求めた.なお, 今回求めた岸・沖移動 距離は, 流速反転時の粒子位置から算出しているため, その鉛直分布は，正確には流速反転時の粒子存在位置に 対する鉛直分布である。

\section{（3） シートフロー層内の質量輸送速度の測定結果}

まずはじめに, シートフロー層内平均質量輸送速度の 測定結果について説明する，写真一1 は, 波を作用させ る前と波を 50 波作用させた後の着色砂の移動状況を示 したものである。これを見ると，着色砂はシートフロー 層内で鉛直方向に差が見られたものの，全体的にかなり 岸向さに輸送されていることがわかる. 一方, 図一2 は 静止時砂面上 $2 \mathrm{~cm}$ の高さの水平流速波形を示したもの だが，これから明らかなように，正弦波形に近いほぼ対 称的な流速波形となっている. これらの結果は，「波動 場に执いてはたと光流速波形が正弦的であっても net の 漂砂量が生じ得る」とした灘岡ら(1988)の指摘を実験事 実の上から裏付けるものである.

ここではさらに，このような岸向き質量輸送状沉をよ り定量的に把握するために, 写真から移動層内にある各 着色砂の座標を読みとり, その存在度数の岸沖方向分布 を調べた．図一3 はその結果を示したものだが，ここで は水槽側壁から見た岸沖方向 $1 \mathrm{~cm}$ 領域ごとの着色粒子 数を度数として表示している. この各度数をその総和で 割った值は，シートフロー層内の底質の鉛直方向に平均 した 50 周期後の移動確率を表すことになる. そこでこ の移動確率から底質粒子の鉛直方向平均質量輸送速度を 算出すると, $0.63 \mathrm{~cm} / \mathrm{s}$ の值を得た.

次に, シートフロー層内質量輸送速度の鉛直分布の測 定結果について説明する. 図一4に示したのがその結果 であり，岸向き，沖向き各方向への底質粒子移動距離の 生データとそれを平均化して求めた net の移動距離を示 している。なた，罒中にはシートフロー層近傍に浮遊さ せは中立粒子の結果も合わせて示してある.

これを見て，まず気付くことは，岸・沖移動距離とも に $z=-0.1 \mathrm{~cm}$ 以下で速度勾配が小さく, それより上 では $z=0 \mathrm{~cm}$ を中心に速度勾配が大きくなっているこ とである。この様な速度勾配の空間的な性質の違いは, ビデオ等による観察から,$z=-0.1 \sim-0.2 \mathrm{~cm}$ 付近を 境とした粒子運動形態の違い（上部：粒子の激しい衝突 と乱れが存在, 下部：粒子同士の接触を基本としたズリ 運動が主体）に対応するものと考えられる.さらに，沖 向きと岸向きで生データの分布状況を比較すると，岸向 き移動距離の方がデータのばらつきが大きいことがわか
る.このことは，岸向き移動時に沖向き移動時よりも強 い乱れが発生していることを示唆しており，この様な岸 向き時と沖向さ時の乱れの発生の相違は, net の移動を 考える上で重要な要素になると考えられる.

さらに今回注目している net の移動距離分布について 見てみると, $z=0 \mathrm{~cm}$ 以下の領域ではその移動量は小さ く, 鉛直方向の速度変化も微小であることがわかる.

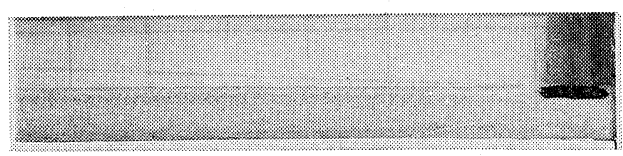

（a）初期状態

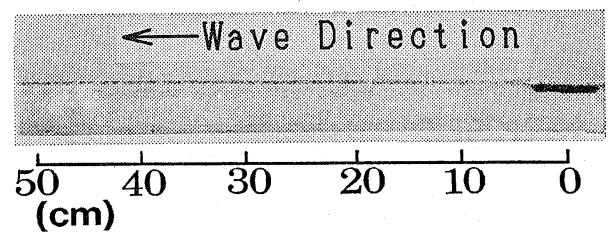

(b) 50 波作用後

写真-1 着色粒子の移動状況

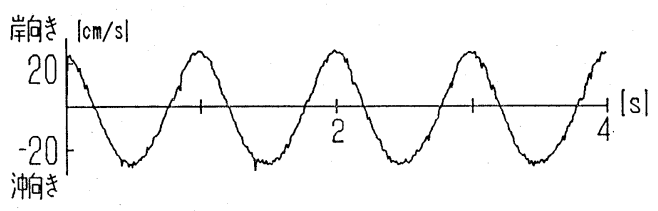

図一2 静止時砂面 $2 \mathrm{~cm}$ 上での水平流速波形

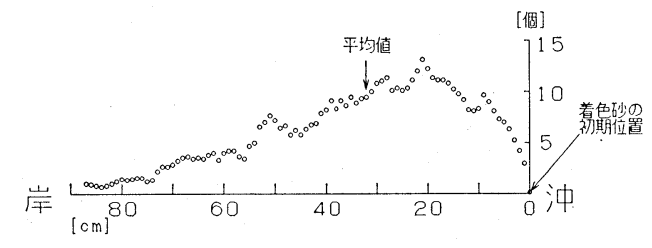

図-3 着色粒子の岸沖方向存在度数分布

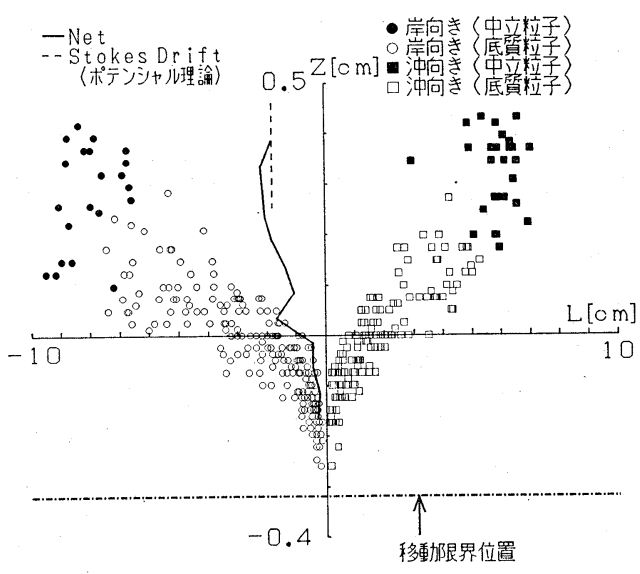

図一4 粒子の岸・沖向き移動距離と net の移動距離 


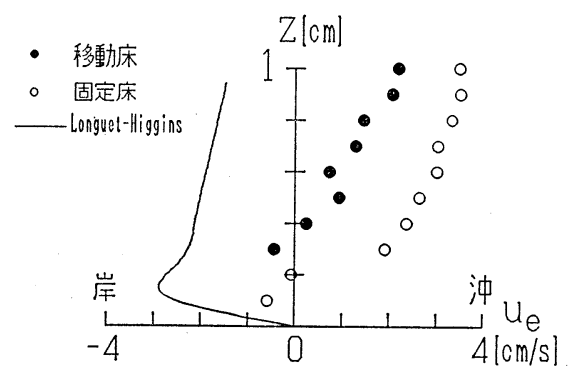

図一5 シートフロー層外縁近傍の Euler 平均速度鉛直分布

$z=0 \mathrm{~cm}$ 付近で急激に増加した後, 上方で正弦波を仮定 したときのポテンシャル理論によるストークスドリフト とほぼ同程度の值となっている. この様に，シートフロ 一層内の質量輸送は，下部の粒子同士の接触を基本とし たズリ運動主体の領域では輸送速度は小さく，上部の粒 子の激しい衝突と乱れが存在する領域のうち, 静止時砂 面 $(z=0.0 \mathrm{~cm})$ より上方で大きな輸送が生じる構造にな っていると若えられる。

\section{（4） シートフロー層外縁付近の Euler 平均速度の} 測定

通常の波動境界層に特いても, Longuet-Higgins(1953) が理諭的に示しているように, 正弦的な波動流速場のも とで粘性効果によって Euler 平均流速が発生する. そし て，それといわゆる Stokes-drift 成分の和で質量輸送速 度が決まることになる、シートフローに执いても，この ようなEuler 流速成分と底質粒子の Stokes drift 成分が 存在すると考えられる. そこで，ここでは Euler 平均流 速に関して FLDV によって測定した結果について述べ る。な抏，測定は同じ水理条件下の固定床に関しても行 った. これは, 固定床上での波動境界層と比較すること によってシートフロー層の底質輸送効果の特徴をより鮮 明にすることをねらったものである.

図一5は，その測定結果を示したもので，LongueHiggins (1953) による理論解もあわせて示してある.こ れを見ると, 固定床, 移動床とも実験值は, 境界層外の 㞍り流れの影響を受けて, 底面近傍まで油向き流速を生 じている. そして結果として， $z=0.3 \sim 0.4 \mathrm{~cm}$ にかけ て Euler 平均流速は 0 に近い值を示していることがわ かる.このことは, 前述のシートフロー層外縁において 質量輸送速度がほぼストークスドリフトに一致するとい う事実を裏付けるものである.

さらに分布形について見てみると，移動床での Euler 平均流速の分布形は固定床に比べて全体的に上にシフト した形となっていることがわかる。移動床においては， 底質が浮遊するため静止時砂面上 $3 \mathrm{~mm}$ までしか計測 ができず，その内部流速については不明である。しかし ながら，後述の理論解析による図一6の結果と照らし合
わせて考えると, シートフロー層内では固定床の場合よ り大きな Euler 平均流速が生じている可能性がある.

\section{3． シートフロー層質量輸送速度に関する理論 解析}

\section{（1）重み付き残差法による解法の概要}

ここでの理論解析は, 灘岡ら(1988)によって提案され た Eilers (1941) の単相有効粘性モデルをべースとした 重み付き残差法に基づく解法を用いている，ただし，基 本的な解法としては灘岡ら(1988) と同じでが，最終的に 用いた式形や境界条件などは多少異なっている. そこ で，ここではそれらの変更点を中心に本解析法の概要を 説明する.

基礎方程式は, 有効粘性係数 $\mu_{e}$, 濃度 $c$ の単相流体 モデルに対する二次元の運動方程式と非圧縮の条件式, それと質量保存式である。これらを波速Cで波とともに 動く座標系で記述し, さらに下記の無次元化を行うと, それぞれ式(1)〜 (4)を得る。

$$
\begin{aligned}
& x^{\prime}=k x, \quad z^{\prime}=\beta z, \quad u^{\prime}=u / u_{0}, \quad w^{\prime}=w / u_{0}(\beta / k) \\
& p^{\prime}=p /\left(\rho_{0} u_{0} C\right), \quad \mu^{\prime}=\mu / \mu_{0}, \quad \rho^{\prime}=\rho / \rho_{0} \\
& -\frac{\partial u}{\partial x}+\frac{u_{0}}{C} u \frac{\partial u}{\partial x}+\frac{u_{0}}{C} w \frac{\partial u}{\partial z}=-\frac{1}{\rho} \frac{\partial p}{\partial x} \\
& +\frac{\nu_{0} k}{C} \frac{1}{\rho} \frac{\partial \mu_{e}}{\partial z} \frac{\partial w}{\partial x}+\frac{\nu_{0} k}{C} \frac{\beta^{2}}{k^{2}} \frac{1}{\rho} \frac{\partial \mu_{e}}{\partial z} \frac{\partial u}{\partial z} \\
& +\frac{\nu_{0} k}{C} \frac{\mu_{e}}{\rho} \frac{\partial^{2} u}{\partial x^{2}}+\frac{\nu_{0} k}{C} \frac{\beta^{2}}{k^{2}} \frac{\mu_{e}}{\rho} \frac{\partial^{2} u}{\partial z^{2}} \\
& +2 \frac{\nu_{0} k}{C} \frac{1}{\rho} \frac{\partial \mu_{e}}{\partial x} \frac{\partial u}{\partial x} \\
& -\frac{k}{\beta} \frac{\partial w}{\partial x}+\frac{k}{\beta} \frac{u_{0}}{C} u \frac{\partial w}{\partial x}+\frac{k}{\beta} \frac{u_{0}}{C} w \frac{\partial w}{\partial z} \\
& =-\frac{\beta}{k} \frac{1}{\rho} \frac{\partial p}{\partial z}+\frac{\nu_{0} k}{C} \frac{k}{\beta} \frac{\mu_{e}}{\rho} \frac{\partial^{2} w}{\partial x^{2}} \\
& +\frac{\nu_{0} k}{C} \frac{\beta}{k} \frac{\mu_{e}}{\rho} \frac{\partial^{2} w}{\partial z^{2}}+2 \frac{\nu_{0} k}{C} \frac{\beta}{k} \frac{1}{\rho} \frac{\partial \mu_{e}}{\partial z} \frac{\partial w}{\partial z} \\
& +\frac{\nu_{0} k}{C} \frac{\beta}{k} \frac{1}{\rho} \frac{\partial \mu_{e}}{\partial x} \frac{\partial u}{\partial z}+\frac{\nu_{0} k}{C} \frac{\beta}{k} \frac{1}{\rho} \frac{\partial \mu_{e}}{\partial x} \frac{\partial w}{\partial x} \\
& \frac{\partial u}{\partial x}+\frac{\partial w}{\partial z}=0 \\
& -\frac{\partial c}{\partial x}+\frac{u_{0}}{C} u \frac{\partial c}{\partial x}+\frac{u_{0}}{C} w \frac{\partial c}{\partial z}=0
\end{aligned}
$$

ここに, $x, y$ : 水平 ·鉛直座標, $u, w$ : 水平鉛直流速, $k$ : 波数, $\beta=2 \pi / \delta$ ( $\delta$ はシートフロー層厚), $u_{0}$ : シー トフロー層外緑での水平流速振幅, $\mu_{0}, \rho_{0}$ ：流体の粘性 係数及び密度を表している。

ここでは, 濃度 $c$ は既知として平均濃度分布 $c(z)$ の 形で与えるものとして式 (4) を基礎方程式系から外し， さらに上式中のパラメータ, $u_{0} / C, k \nu_{0} / C, k / \beta$ はともに 微小と考えて，それらがかかる項をすべて消去すると， 
式(1)〜 (3)は，次式のようになる.

$$
\begin{aligned}
& \frac{\partial u}{\partial x}-\frac{1}{\rho} \frac{\partial p}{\partial x}+\frac{\nu_{0} k}{c} \frac{\beta^{2}}{k^{2}} \frac{\mu_{e}}{\rho} \frac{\partial^{2} u}{\partial z^{2}} \\
& +\frac{\nu_{0} k}{c} \frac{\beta^{2}}{k^{2}} \frac{1}{\rho} \frac{\partial \mu_{e}}{\partial z} \frac{\partial u}{\partial z}=0 \\
& 0=-\frac{1}{\rho} \frac{\partial p}{\partial z} \\
& \frac{\partial u}{\partial x}+\frac{\partial w}{\partial z}=0
\end{aligned}
$$

上式で, 式 (6) から $p(z)$ は境界層外縁の圧力で決末り, その結果, 式(5)で $u$ が独立に求められる形になる。 そ して最終的に, 式 (7) に $u$ を代入して $w$ を計算するこ とになる。

$u$ に関する式 (5) を解くに当たって, 複素関数表示, 式（8）を導入すると，最終的に解くべき方程式系として 式 (9)，(10) を得る.

$$
\begin{aligned}
& u=R_{e}\left\{\left(u_{r}(z)+i u_{i}(z)\right) \exp (i x)\right\} \\
& u_{r}-\frac{1}{\rho} p_{0}+\frac{\nu_{0} \beta^{2}}{\sigma} \frac{\mu_{e}}{\rho} \frac{\partial^{2} u_{i}}{\partial z^{2}}+\frac{\nu_{0} \beta^{2}}{\sigma} \frac{1}{\rho} \frac{\partial \mu_{e}}{\partial z} \frac{\partial u_{i}}{\partial z} \\
& =0 \\
& -u_{i}+\frac{\nu_{0} \beta^{2}}{\sigma} \frac{1}{\rho} \frac{\partial^{2} u_{r}}{\partial z^{2}}+\frac{\nu_{0} \beta^{2}}{\sigma} \frac{1}{\rho} \frac{\partial \mu_{e}}{\partial z} \frac{\partial u_{i}}{\partial z} \\
& =0
\end{aligned}
$$

ここで $\boldsymbol{\sigma}$ は角振動数である.

上記の方程式系の具体的な解法としては, 灘岡ら (1988) と同様に, Hermite 関数を試験関数とした Galerkin 法を用いた. その際の境界条件は下記のとうりで ある。

$$
\begin{array}{lll}
u_{r}=1, & u_{i}=0 & z=\infty \\
u_{r}=0, & u_{i}=0 & z=-\infty
\end{array}
$$

な拉，灘岡ら(1988)はシートフロー層下端以深に括け る粒子の静止状態を表現するために，シートフロー層の 駆動力である圧力勾配を便宜的に濃度の関数として補正 する形で与え, 最大濃度以深ではゼロとする操作を施し ている.しかしながら，そのよらな取り扱いではシート フロー層下部の高濃度領域の流動状態に関して本来有効 粘性の増大による流動性の低下に加えて，圧力勾配を人 為的に減少させることで流動性の低下を二重に考慮する ことになる，そこで，ここでは有効粘性のモデルの一貫 性を考慮して，粒子の流動性の低下は有効粘性係数のみ で表現するようにした。具体的には，有効粘性的を最大 濃度領域で無限大になる形に設定することで粒子の静止 状態を表現するようにしたが，そのため式（9)，(10）を $\mu_{0}$ で除した形でその後の数式展開を行っている.

また，上記の平均濃度の鉛直分布 $c(z)$ としては，ビ デオ撮影によって測定したシートフロー層厚に基つい て, tanh 関数で与えた.

（2）室内実験との比較
本解析法を用いて，室内実験と同じ水理条件ならびに 底質条件で計算を行い，その結果から移動層内の質量輸 送速度 $u_{L}$ を構成する, Stokes drift $u_{S}$ 及び Euler 的平 均速度 $u_{E}$ を次式によって算出した。

$$
\begin{aligned}
& u_{L}=u_{E}+u_{S} \\
& u_{S}=\overline{\frac{\partial u}{\partial x} \int u d t}+\overline{\frac{\partial u}{\partial z} \int w d t} \\
& u_{E}=\frac{\rho}{\mu_{e}} \int_{0}^{z}\left(\overline{u w}_{\infty}-\overline{u w}\right) d z
\end{aligned}
$$

その結果を示したのが図一6である。これを見ると， Stokes drift についてはその大きさが静止時砂面よりや や上で最大となりそれより上で泳一定となって固定床 時の Stokes drift に一致している形になっている。 ま た, Euler 的質量輸送速度は, $z=0.2 \mathrm{~cm}$ 付近のピーク でかなり膨らんだ分布形となり，シートフロー層上層で 固定床上の Euler 的質量輸送速度より大きな速度を発生 していることがわかる.

次に, この結果と前述の室内実験よって測定されたシ ートフロー層内の質量輸送速度の比較を試みた. その結 果を示したのが図一7 である。これを見ると，領域全体 にわたり，実験值は計算值の半分程度の大きさになって いる.ささらに, この解析結果から濃度分布を用いて層内 平均輸送速度を算出し, それと前述の着色砂を用いた首 内平均の実験值と比較してみた。 それによれば，実験に よる風内平均速度 $0.63 \mathrm{~cm} / \mathrm{s}$ に対して解析結果は 0.79

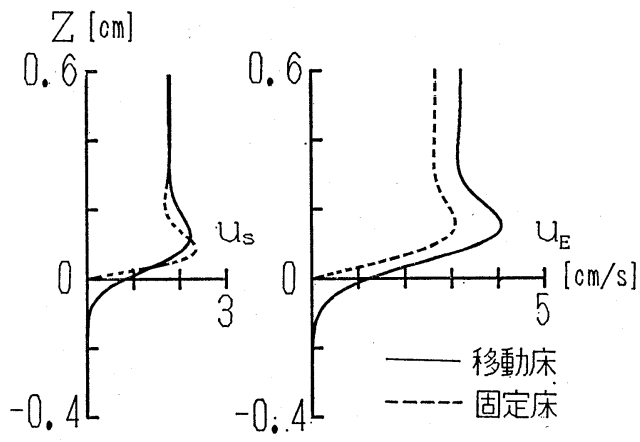

図一6 質量輸送速度の鉛直分布

Z [om]

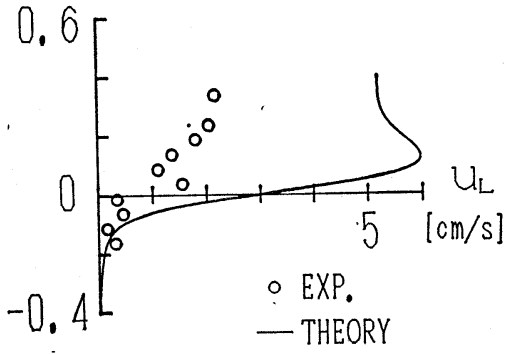

図一7 質量輸送速度の室内実験との比較 
$\mathrm{cm} / \mathrm{s}$ となり，鉛直分布の場合と対応して層内平均值で も実験值の方が小さくなってる．この様な結果となった 主な原因としては，図一5 に示したEuler 平均流速の分 布かららかがえるように，実験の場合移動層上部で内部 領域の戻り流れの影響を受け Euler 平均流速がほぽ 0 に なっているのに対して, 理論解析ではこの様な効果を考 虑していないことが考它られる。したがって，今後さら に精度の良い予測をするためには戻り流れの効果まで含 めた解析が必要となる。さらに，今回の理論解析では $c(z)$ や $\mu_{i}(z)$ を時間的に固定しているため，そのこと が実験值との差を生じさせている原因となっている可能 性があり，この面での改良も必要である。(なお，図一4 で見る限り中立粒子と底質粒子のデータがほぼ連続的に つながっていることから, 単相モデルで扱っていること の影響は，少なくとも今回の実験条件に対してはあまり 大きくないものと考兄られる.)

\section{（3）底質の密度効果に着目した解析}

シートフロー層内の質量輸送を支配している要素とし ては，層内の運動量交換を規定している有効粘性係数の 関数形々密度変化に伴う場所的な慣性効果の違い(以後, 密度効果と呼ぶことにする）があると考光られる。そこ で今回は，この二つのうち密度効果に着目してその性質 を調べてみた，図一8 は室内実験に対応する底質密度 $s=1.3$ の場合 (点線) に加えて通常の砂に対応する $s=$ 2.6 の場合 (実線) と, それと同等の有効性係数の分布を 持ち比重だけ 1.0 と場全体で一定にした時（一点鎖線） の計算結果を, 流速振幅と Euler 平均流速の両方につい て示したものである．まず（a）の流速振幅を見ると， $s$ が大きくなるにつれて上層でのオーバーシュートが見ら れなくなる形に変化していることがわかる．一方，(b) の Euler 平均流速の分布形を見ると， $s$ の増大に対応し てシートフロー層外縁での $u_{E}$ が大きくなっている. こ

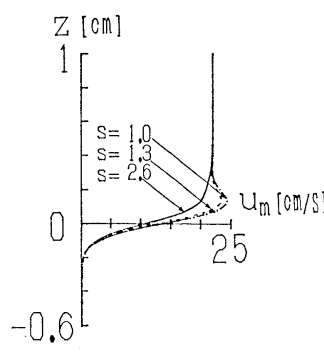

(a) 流速振幅

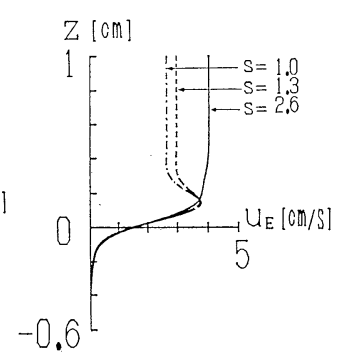

(b) Euler平均速度
図-8 流速振幅と Euler 平均速度の鉛直分布 れは，密度変化にともなら場所的な慣性の違いが，(a) に見られるよらな水平波動流速振幅の分布形を变形さ せ, それが Euler 平均速度の相違を引き起こしているこ とを示すものである，この様な密度効果による Euler 平 均流速の変化は, 図一8(b)の結果からうかがえるように 実際の $s=2.6$ 程度の砂粒子の質量輸送を扱う際に特に 重要な要素となる可能性がある.

\section{4.おわりに}

今回得られた主な結論忖のとらりである.

(1)正弦的な波動流速場に拈いても有意な大きさで底質が 岸向きに輸送されることを室内実験によって明らかに し, 水粒子の場合と同様に波動場に淤ける質量輸送が シートフロー状砂移動においても重要になりうること を示した。

(2)室内実験によって, シートフロー層内の質量輸送速度 の鉛直分布を計測した結果, 静止時の砂面 $(z=0 \mathrm{~cm})$ 近傍で質量輸送速度は, 急激に大きくなり, それより 下の質量輸送速度は非常に小さいことがわかった。

(3)理論解析によって底質の質量輸送速度を算出し, その 結果を実験による層内鉛直分布, 首内平均速度と比較 した. その結果, 両者とも実験值の方が解析結果より も小さくなった，その原因としては，シートフロー層 外部の戻り流れの効果及び $c(z), \mu_{o}(z)$ の時間変動の 効果等が考学られる.

(4)また, 質量輸送速度の構造に抒いてシートフロー層内 の密度効果が重要となることが示された。

なお，本研究は文部省科学研究費奖励研究 (a)（課題 番号: 02750425, 研究代表者：八木宏）の補助を受けて 行われたものである。ここに記して謝意を表します。

\section{参 考 文 献}

榊山 勉・Eco W. Bijker (1988)：波による海底粘性土の質量 輸送, 電力中央研究所報告,

灘岡和夫 ·上野成三・八木 宏 (1988)：波動場と振動流場の違 いに着目したシートフローの理論解析, 第 35 回海岸工学講 演会論文集, pp. 292-296.

Eilers, H. (1941): Die Viskositat von Emulsionen ho chviskoser Stoffe als Funktion der Konzentrazionen, Kolloid, Z., 97, pp. 317-321.

Longuet-Higgins, M. S. (1953): Mass transport in water waves, Phil. Trans. Royal Soc., London, Series A, No. 903, Vol. 245, pp. 535-581. 